\title{
PENGARUH KONSELING TERHADAP SIKAP AKSEPTOR SUNTIK 3 BULANAN TENTANG EFEK SAMPING PENAMBAHAN BERAT BADAN DI KLINIK HARAPAN BUNDA PANGKALAN BUN
}

\author{
${ }^{1}$ Dhita Yuniar Kristianingrum \\ ${ }^{1}$ STIKes Borneo Cendekia Medika \\ ${ }^{1}$ Email.dhitacr.iestd@gmail.com
}

\begin{abstract}
ABSTRAK
Fenomena dimasyarakat banyak ibu cenderung bersikap negatif untuk melakukan penanganan efek samping penambahan berat badan. Sehingga, peningkatan informasi bisa dilakukan melalui konseling dibutuhkan untuk mengatasi masalah yang ada di masyarakat. Berdasarkan hasil studi pendahuluan melalui wawancara pada tanggal 12 Juli 2017 pada 10 Akseptor KB suntik 3 bulan didapatkan seluruh akseptor mengalami kenaikan berat badan. Tujuan dari penelitian ini adalah menganalisis pengaruh konseling terhadap sikap akseptor suntik 3 bulanan tentang efek samping penambahan berat badan di Klinik Harapan Bunda Pangkalan Bun. Penelitian ini menggunakan desain pra-eksperimental one group pre-post test design. Populasi pada penelitian ini Semua akseptor suntik 3 bulanan yang mengalami penambahan berat badan di Klinik Harapan Bunda Pangkalan Bun sebanyak 138 orang. Pengambilan sampel sejumlah 28 siswa secara simple random sampling. Variabel independent adalah konseling. Variabel dependent adalah sikap akseptor suntik 3 bulanan tentang efek samping penambahan berat badan. Pengumpulan data pada penelitian ini menggunakan kuesioner. Teknik pengolahan data menggunakan Editing, Coding, Scoring dan Tabulating. Analisa data menggunakan Univariate dengan T Mean dan Bivariate dengan uji Paired $t$ test. Hasil penelitian pada 28 respoden didapatkan bahwa 16 responden $(57,1 \%)$ bersikap negatif dan 12 responden $(42,9 \%)$ bersikap positif sebelum diberi konseling. Setelah diberi konseling menjadi 20 responden $(71,4 \%)$ bersikap positif dan 8 responden $(28,6 \%)$ bersikap negatif. Hasil uji statistik didapatkan taraf signifikan sebesar 0,003 adalah kurang dari $0,05(\rho=0,003<\alpha=0,05)$. Kesimpulannya ada pengaruh konseling terhadap sikap akseptor suntik 3 bulanan tentang efek samping penambahan berat badan.
\end{abstract}

\section{Kata Kunci : Sikap, Konseling, Akseptor, Berat badan}

THE EFFECT OF COUNSELING ON ATTITUDE OF 3 MONTHLY INJECTION ACCEPTORS ON THE EFFECTS OF WEIGHT ADDITIONAL AGENCY IN THE HOPE OF PANGKALAN BUNDA PUNKALAN BUNDA

\section{ABSTRAK}

Phenomenon in the community many mothers tend to be negative in handling the side effects of weight gain. Thus, increasing information can be done through counseling needed to overcome problems that exist in society. Based on the results of a preliminary study through interviews on July 12, 2017, on 10 injectable KB acceptors in 3 months, all acceptors gained weight. The purpose of this study was to analyze the effect of counseling on the attitude of 3-month injecting acceptors about 
the side effects of weight gain at the Harapan Bunda Bun Clinic at Pangkalan Bun. This study uses a pre-experimental one group pre-post test design. The population in this study were all 3 monthly injecting acceptors who experienced weight gain at Harapan Bunda Pangkalan Bun Clinic as many as 138 people. Sampling of 28 students by simple random sampling. The independent variable is counseling. The dependent variable is the attitude of 3-month injecting acceptors about the side effects of weight gain. Data collection in this study using a questionnaire. Data processing techniques using Editing, Coding, Scoring and Tabulating. Data analysis using Univariate with $T$ Mean and Bivariate with Paired t test. The results of the study on 28 respondents found that 16 respondents (57.1\%) were negative and 12 respondents (42.9\%) were positive before being counseled. After being counseled, 20 respondents (71.4\%) were positive and 8 respondents $(28.6 \%)$ were negative. Statistical test results obtained a significant level of 0.003 is less than 0.05 ( $\rho=$ $0.003<\alpha=0.05$ ). In conclusion there is the effect of counseling on the attitude of 3 month injecting acceptors about the side effects of weight gain.

Keywords: Attitude, Counseling, Acceptor, Weight

\section{PENDAHULUAN}

Berat badan merupakan ukuran antropometri yang terpenting yang digunakan sebagai ukuran laju pertumbuhan fisik, disamping itu berat badan digunakan sebagai ukuran perhitungan dosis obat dan makanan. Berat badan menggambarkan jumlah dari protein, lemak, air, dan mineral pada tulang. Salah satu efek samping dari metode suntikan adalah adanya penambahan berat badan. Umumnya pertambahan berat badan tidak terlalu besar, bervariasi antara kurang dari satu kilogram sampai lima kilogram dalam tahun pertama (Suparyanto, 2013).

Berdasarkan hasil penelitian yang dilakukan oleh Universiti of Texas Medical Branch (UMBT), wanita yang menggunakan kontrasepsi (DMPA) atau dikenal dengan KB suntik 3 bulan, rata- rata mengalami peningkatan berat badan sebanyak 5,5 $\mathrm{kg}$ dalam waktu 3 tahun pemakaian. Dimana penelitian yang dilakukan tersebut melibatkan 703 wanita PUS. Peneliti membandingkan penggunaan DMPA memiliki resiko 2 kali lipat dibandingkan pengguna kontrasepsi lainnya untuk mengalami obesitas selama 3 tahun pemakaian (Mardiyaningsih, 2012).

Hasil penelitian yang dilakukan oleh Siti Hawa Mahmud di Bidan Praktik Swasta Maria Purba, Surabaya Barat, Jawa Timur tentang perbedaan antara pemakaian kontrasepsi suntik kombinasi dan suntik depomedroxy progesteron acetat (DMPA) dalam perubahan berat badan ditemukan jumlah sampel ibu yang memakai kontraspsi suntik periode OktoberNovember tahun 2011 sebanyak 267. Dari penlitian ini diketahui sebagian besar akseptor menggunakan suntik kombinasi $(85,59 \%)$ mengalami kenaikan berat badan, hampir seluruh akseptor menggunakan kontrasepsi suntik DMPA $(97,99 \%)$ mengalami kenaikan berat badan. 
Penggunaan suntik DMPA yang mengandung hormon progesteron dapat mempermudah perubahan karbohidrat dan gula menjadi lemak, sehingga lemak di bawah kulit bertambah. Selain itu hormon progesteron juga menyebabkan nafsu makan bertambah dan menurun aktivitas fisik, akibatnya pemakaian suntik dapat menyebabkan berat badan bertambah (Varney, 2007). Faktor-faktor yang mempengaruhi sikap ibu dalam penanganan efek samping penambahan berat badan antara lain pengetahuan, informasi, kondisi keluarga, pendidikan dan lingkungan. (Azwar, 2011). Kurangnya informasi menyebabkan banyak ibu yang cenderung bersikap negatif untuk melakukan penanganan efek samping penambahan berat badan. Sehingga, peningkatan informasi yang bisa dilakukan melalui konseling sangat dibutuhkan untuk mengatasi masalah yang ada di masyarakat.

Solusi dalam penanganan efek samping KB telah dilakukan oleh bidan dengan memberikan informasi melalui konseling mengenai metode kontrasepsi serta efek samping yang terjadi terhadap akseptor baru. Akan tetapi, tidak banyak ibu yang memahami dan cenderung bersikap negatif dalam melakukan penanganan efek samping. Maka dari itu perlu dilakukan peningkatkan konseling, sehingga diharapkan mampu memberikan dampak positif terhadap sikap akseptor suntik dalam melakukan penanganan efek samping KB serta akseptor dapat memahami perubahan hormonal yang diakibatkan kontrasepsi suntik 3 bulan. Untuk itu perlu dilakukan penelitian yang lebih mendalam dengan menarik judul penelitian "Pengaruh Konseling terhadap Sikap Akseptor Suntik 3 Bulanan tentang Efek Samping
Penambahan Berat Badan di Klinik Harapan Bunda Pangkalan Bun.”

\section{Konsep Konseling}

Konseling adalah proses yang berjalan dan menyatu dengan semua aspek pelayanan keluarga berencana dan bukan hanya informasi yang diberikan dan dibicarakan pada satu kali kesempatan yakni pada saat pemberian pelayanan. Teknik konseling yang baik dan informasi yang memadai harus diterapkan dan dibicarakan secara interakif sepanjang kunjungan klien dengan cara sesuai dengan budaya yang ada (Handayani, 2010)

Tujuan dalam pemberian konseling keluarga berencana antara lain :

a. Meningkatkan penerimaan Informasi yang benar, diskusi bebas dengan cara mendengarkan, berbicara dan komunikasi non verbal meningkatkan penerimaan KB oleh klien.

b. Menjamin pilihan yang cocok

Konseling menjamin bahwa petugas dan klien akan memilih cara yang terbaik sesuai dengan keadaan kesehatan dan kondisi klien.

c. Menjamin penggunaan cara yang efektif

Konseling yang efektif diperlukan agar klien mengetahui bagaimana menggunakan cara $\mathrm{KB}$ yang benar, dan bagaimana mengatasi informasi yang keliru dan isu-isu tentang cara tersebut.

d. Menjamin kelangsungan yang lebih lama

Kelangsungan cara KB akan lebih baik bila klien ikut memilih cara tersebut, mengetahui bagaimana cara kerjanya dan bagaimana mengatasi efek sampingnya. Kelangsungan pemakaian juga lebih baik bila ia mengetahui bahwa ia dapat berkunjung 
kembali seandainya ada masalah. Kadang-kadang klien hanya ingin tahu kapan ia harus kembali untuk memperoleh

(Handayani, 2010).

pelayanan

Adapun jenis-jenis dari konseling adalah sebagai berikut :

a. Konseling KB awal atau Pendahuluan dilakukan pada mereka yang sama sekali belum tahu KB, belum mengerti norma keluarga kecil bahagia sejahtera (NKKBS).

b. Konseling KB Pemilihan Cara

Dilakukan pada mereka yang sudah mengerti NKKBS dan membutuhkan pertolongan atau bantuan dalam memilih cara-cara atau alat/obat kontrasepsi, misalnya karena belum tahu pengeahuannya masih kurang lengkap. Bisa juga karena pengetahuannya kurang lengkap bisa juga karena pengetahuannya kurang tepat atau keliru.

c. Konseling KB Pemantapan

Dilakukan pada mereka yang sudah memahami. Tujuannya ialah supaya yakin bahwa alat/obat kontrasepsi yang akan dipakainya sesuai dengan kondisi dan kebutuhannya, tahu kemungkinan efek samping dan cara mengatasinya.

d. Konseling KB Pengayoman

Dilakukan pada mereka yang sudah memakai kontrasepsi.

Tujuannya adalah untuk mengatasi masalah yang timbul sesudah memakai alat kontrasepsi.

e. Konseling KB Perawatan/Pengobatan Dilakukan pada mereka yang mengalami kegoncangan emosi atau gangguan kejiwaan akibat keinginannya untuk memiliki KKBS maupun karena memakai alat kontrasepsi. (Setya Arum, D. N \& Sujiyatini, 2010)
Teknik-teknik konseling yang biasa dipergunakan :

1. Cara supoortif untuk memberi dukungan kepada peserta atau calon peserta, karena mereka dalam keadaan bingung dan raguragu yaitu dengan menenangkan atau menentramkan dan menumbuhkan kepercayaannya bahwa ia mempunyai kemampuan untuk membantu dirinya sendiri.

2. Kataris : dengan memberikan kesempatan kepada mereka untuk mengungkapkan dan menyalurkan semua perasaan-perasaan yang tersirat dalam ucapan-ucapannya.

3. Membuat refleeksi dan kesimpulan atas ucapan-ucapan serta perasaanperasaan yang tersirat dalam ucapan-ucapannya.

4. Memberi semua informasi yang diperlukannya untuk membantu peeserta atau calon peserta membuat keputusan.

Dalam konseling diadakan percakapan dua arah untuk :

a. Membahas dengan calon peserta berbagai pilihan kontrasepsi yang tersedia.

b. Memberikan informasi selengkap mungkin mengenai konsekuensi pilihannya, baik ditinjau dari segi medis teknik maupun hal-hal lain yang non medis agar tidak menyesal kemudian.

c. Membantu calon peserta KB memutuskan pilihannya atas metode kontrasepsi yang paling sesuai dengan keadaan khusus pribadi dan keluarganya.

d. Membantu peserta KB dalam penyesuaian diri terhadap kondisi barunya, terutama bila ia mengalami berbagai permasalahannya (nyata atau tidak nyata/semu) (Setya Arum, D. N \& Sujiyatini, 2010).

\section{Konsep Dasar Sikap}


Semua kegiatan atau aktifitas manusia, baik dapat diamati langsung maupun tidak langsung yang diamati oleh pihak luar. Sikap adalah keyakinan mengenai tersedianya atau tidaknya kesempatan dan sumber yang diperlukan (Notoatmodjo, 2011).

Menurut Lawrence yang dikutip oleh Notoatmodjo (2011) bahwa sikap itu sendiri dipengaruhi oleh beberapa faktorfaktor yaitu :

1. Faktor predisposising : yang terwujud dalam pengetahuan, sikap, kepercayaan keyakinan dan nilai-nilai.

2. Faktor pendukung : yang terwujud dalam lingkungan fisik, tersedia atau tidak bersedianya

fasilitas-fasilitas atau sarana-sarana kesehatan. Misalnya : Puskesmas, obat-obatan, alat-alat kontrasepsi.

3. Faktor pendorong : yang terwujud dalam sikap dan sikap petugas kesehatan atau petugas lainnya yang merupakan kelompok retefensi dari sikap masyarakat.

Menurut Notoatmodjo (2011) sifat sikap terdiri dari :

a. Sikap positif kecenderungan tindakan adalah mendekati, menyenangi, mengharapkan obyek tertentu.

b. Sikap negatif terdapat kecenderungan untuk menjauhi, menghindari, membenci, tidak menyukai obyek tertentu.

Pengukuran sikap dapat dilakukan dengan menilai pertanyataan sikap seseorang. Pernyataan sikap adalah rangkaian kalimat yang mengatakan sesuatu mengenai obyek sikap yang berhak diungkap. Cara pengukuran sikap dengan Skala likert (Hidayat, 2010).

Pernyataan sikap mungkin berisi atau mengatakan hal yang positif mengenai objek sikap, yaitu kalimatnya bersifat mendukung atau memihak pada objek sikap. Pernyataan ini disebut dengan pernyataan yang favourable. Sebaliknya pernyataan sikap mengkin pula berisi hal yang negatif mengenai obyek sikap yang bersifat tidak mendukung maupun kontra terhadap obyek sikap. Pernyataan seperti ini disebut dengan pernyataan yang tidak favourable.

Suatu skala sikap sedapat mungin diusahakan agar terdiri atas pernyataan favourable dan non favourable dalam jumlah yang seimbang. Dengan demikian pernyataan yang disajikan tidak semua positif dan tidak semua negatif yang seolah isi skala memihak atau tidak mendukung sama sekali objek sikap (Azwar, 2011). Pengukuran sikap dapat dilakukan secara langsung atau tidak langsung. Secara langsung dapat dinyatakan bagaimana pendapat atau pernyataan responden terhadap suatu obyek. Secara tidak langsung dapat dilakukan dengan pernyataan hipotesa kemudian ditanyakan pendapat responden melalui kuesioner (Notoatmodjo, 2010).

\section{Konsep Akseptor}

Akseptor adalah pasangan usia subur (PUS) yang menggunakan salah satu alat kontrasepsi (BKKBN, 2011).

Macam-macam Akseptor

a. Akseptor Aktif

Adalah Akseptor yang pada saat ini memakai kontrasepsi untuk menjarangkan kehamilan atau yang mengakhiri kehamilan.

b. Akseptor Baru

Adalah Akseptor yang baru pertama kali menggunakan alat kontrasepsi atau yang menjadi akseptor setelah melahirkan atau abortus.

c. Akseptor Dini 
Adalah para ibu yang menerima salah satu cara kontrasepsi dalam waktu 2 minggu setelah melahirkan atau abortus.

d. Akseptor Droup Out

Adalah akseptor yang menghentikan pemakaian kontrasepsi lebih dari 3 bulan.

e. Akseptor Langsung

Adalah para ibu yang memakai salah satu cara kontrasepsi dalam waktu 40 hari setelah melahirkan atau abortus.

f. Akseptor Lestari

Adalah akseptor yang mempergunakan alat kontrasepsi dengan cara terus menerus dalam waktu sekurang-kurangnya 5 tahun.

g. Akseptor Manual

Adalah orang-orang yang mendukung norma keluarga kecil yang bahagia dan sejahtera (NKKBS) didalam sikap hidupnya khususnya generasi muda yang menunda perkawinan (BKKBN, 2011)

\section{Konsep Dasar KB (Keluarga Berencana)}

Keluarga berencana (family planning) adalah gerakan untuk mewujudkan keluarga kecil sejahtera dan bahagia melalui penurunan tingkat kelahiran secara bermakna. (Yanti, 2011)

Tujuan umum untuk lima tahun kedepan mewujudkan visi dan misi program $\mathrm{KB}$ yaitu membangun kembali dan melesarikan pondasi yang kokoh bagi pelaksana program $\mathrm{KB}$ di masa mendatang untuk mencapai keluarga berkualitas tahun 2015.

Macam-macam KB :

a. Metode sederhana meliputi :

1) Tanpa alat yaitu KB alamiah (Metode kalender (OginoKnaus), Metode Suhu Basal
(Termal), Metode lendir serviks (Billings), Metode Simpto-Termal) dan Coitus Interuptus.

2) Dengan alat yaitu Mekanis (Barrier) [Kondom Pria, Barier intra-vaginal (Diafragma, Kap Serviks (Cervical cap), Spons (Sponge), Kondom wanita] dan kimiawi [Spermisid (Vaginal cream, Vaginal foam, Vaginal Jelly, Vaginal suppositoria, Vaginal tablet (busa), Vaginal soluble film].

b. Metode modern

1) Kontrasepsi hormonal yaitu Per-oral [Pil Oral Kombinasi (POK), Mini-pil, Morningafter pill], Injeksi atau suntikan [DMPA, NET-EN, Microspheres, Microcapsules] dan Sub-kutis : Implant (Alat kontrasepsi bawah kulit = AKBK), Implant Nonbiodegradable (Norplant, Norplant-2, ST-1435, Implanon), Implant Biodegradable (Capronor, Pellets).

2) Intra uterie devices (IUD, AKDR)

3) Kontrasepsi mantap : pada wanita (tubektomi) dan pada pria (vasektomi). (Setya Arum, D. N \& Sujiyatini, 2010)

\section{Konsep Kontrasepsi Suntik}

Kontrasepsi suntikan di Indonesia merupakan salah satu kontrasepsi yang populer. Kontrasepsi yang digunakan ialah long-acting progestin, yaitu Noritisteron enantat (NETEN) dan Depomedroksi Progesterone acetat (DMPA) (Sarwono, 2009).

Kontrasepsi suntik adalah salah satu jenis kontrasepsi yang mengandung 
hormone progesterone yang berdaya kerja lama (panjang), yang tidak membutuhkan pemakaian setiap hari atau setiap akan bersenggama tetapi tetap reversible (Hanafi, 2004).

Macam-macam KB Suntik dan jadwal :

a. Depoprovera : Interval 12 minggu

b. Norigest : Interval 8 minggu untuk 4 kali suntikan berikutnya dan injeksi kelima diberikan setiap 12 minggu

c. Cyclofem : Interval 4 minggu

Keuntungan KB Suntik :

a. Pemberiannya sederhana setiap 8 12 minggu

b. Tingkat efektifitasnya tinggi $(99,6 \%)$

c. Hubungan seks dengan suntikan KB bebas

d. Pengawasan medis yang ringan

e. Dapat dipakai - diberikan pasca persalinan, pasca keguguran atau pasca menstruasi

f. Tidak menggangu pengeluaran laktasi dan tumbuh kembang bayi

g. Suntikan KB cyclofem diberikan setiap bulaln dan peserta $\mathrm{KB}$ akan mendapatkan menstruasi

h. Reaksi suntikan sangat cepat $(<24$ jam) (Hanafi, 2001).

Kerugian Suntikan KB :

a. Perdarahan yang tidak menentu

b. Terjadi amenorrhoe (tidak datang bulan)berkepanjangan

c. Masih terjadi kemungkinan hamil

d. Permasalahan berat badan merupakan efek samping tersering

e. Harus kembali ke sasaran pelayanan (Hanafi, 2004)

Indikasi dan Kontra indikasi KB Suntik :

a. Indikasi

1. Perempuan usia reproduksi

2. Perempuan yang telah memiliki anak

3. Perempuan yang ingin mendapatkan kontrasepsi dengan efektifitas yang tinggi
4. Permpuan yang menyusui ASI pasca persalinan $>6$ bulan

5. Perempuan pasca persalinan dan menyusui

6. Perempuan dengan tekanan darah < 180/110 mmHg. Dengan masalah gangguan pembekuan darah atau perempuan dengan anemia

7. Perempuan dengan nyeri haid hebat

8. Perempuan dengan riwayat kehamilan ektopik

9. Perempuan yang sering lupa mengguanakan pil kontrasepsi

b. Kontra indikasi

1. Perempuan hamil atau diduga hamil (resiko cacat pada janin 7 per 100.000 kelahiran)

2. Perempuan dengan perdarahan pervaginam yang belum jelas penyebabnya

3. Perempuan dengan keganasan pada payudara (Saifuddin, 2006).

\section{Konsep Perubahan Berat Badan}

Faktor internal

a. Faktor herediter

Faktor herediter merupakan faktor turunan secara genetik. Misalnya ras atau suku bangsa tertentu memiliki kecenderungan lebih besaratau lebih kecil.

b. Faktor hormonal

Faktor hormonal yang mempengaruhi penambahan berat badan misalnya hormon tiroid yang menstimulasi metabolisme tubuh dan hormon pertumbuhan yang menstimulasi terjadinya poliferasi sel. Pemakaian kontrasepsi suntik 3 bulan juga akan mempengaruhi penambahan berat badan. Hal ini dikarenakan kandungan progesteron dalam kontrasepsi suntik 3 bulan akan menambah nafsu makan sehingga berat badan cenderung mengalami penambahan. 
Faktor eksternal

a. Faktor nutrisi

Nutrisi adalah salah satu komponen penting yang menunjang berat badan ibu. Manusia membutuhkan zat gizi seperti protein, karbohidrat, lemak, mineral, vitamin dan air. Apabila kebutuhan tersebut tidak atau kurang terpenuhi maka penambahan berat badan akan terhambat.

b. Faktor iklim atau cuaca

Iklim dan cuaca merupakan salah satu faktor pertumbuhan manusia. Pada musim tertentu, makanan bergizi dapat mudah diperoleh atau sebaliknya justru menjadi sulit diperoleh. Misalnya pada musim kemarau sumber makanan atau hasil panen sebagai faktor pemenuhan gizi.

c. Faktor olahraga/latihan fisik dan aktivitas

Olahraga, latihan fisik dapat memacu pertumbuhan karena meningkatkan sirkulasi darah sehingga pasokan oksigen keseluruh tubuh menjadi teratur. Sehingga dapat meningkatkan stimulasi pertumbuhan berat badan seseorang.

d. Faktor status kesehatan/penyakit Status kesehatan atau penyakit yang diderita dapat berpenmgaruh pada percepatan penambahan berat badan. Sebaliknya apabila kondisi kesehatan kurang baik maka akan terjadi keterlambatan.

e. Faktor status sosial ekonomi

Status sosial ekonomi juga akan mempengaruhi pertumbuhan. Seseorang yang dilahirkan dan dibesarkan dalam lingkungan yang status ekonominya tinggi cenderung lebih tercukupi kebutuhan gizinya sehingga lebih memiliki berat badan yang berlebihan.
Pengaruh Konseling terhadap Sikap

Proses konseling pada dasarnya proses perubahan perilaku individu dalam sistem, dan kepedulian utamanya terletak pada interaksi individu dalam sistem. Individu dalam sistem mempunyai tujuan yang ingin dicapai melalui konseling. Tujuan yang ingin dicapai adalah perubahan perilaku pada diri individu, baik dalam bentuk pandangan, sikap, sifat maupun keterampilan yang lebih memungkinkan individu dapat menerima, mewujudkan diri, mengembangkan diri, mencegah dan mampu mengatasi permasalahan secara optimal sebagai wujud dari individu yang memiliki pribadi mandiri (Corones, 2009).

\section{BAHAN DAN METODE PENELITIAN}

Pada penelitian ini penulis menggunakan desain penelitian Praeksperiment dengan rancangan onegroup pretest postest design.

Bentuk rancangan ini sesuai dengan pola yang dijelaskan pada tabel 1.1.

Tabel 1.1 Rancangan one-group pretest postest design

Subyek Pretest Perlakuan Post

\begin{tabular}{llll} 
& & & test \\
\hline $\mathrm{K}$ & Xo & $\mathrm{X}$ & $\mathrm{X} 1$ \\
& Waktu & Waktu 2 & Waktu \\
& 1 & & 3 \\
\hline
\end{tabular}

Sumber : Nursalam 2011

Keterangan :

K : subyek

: sebelum diberikan

Xo perlakuan

$\mathrm{X} \quad$ : intervensi

: sesudah diberikan

X1 perlakuan

Penelitian ini dilaksanakan pada bulan Juli 2017. Penelitian ini akan dilakukan di Klinik Harapan Bunda. 
Pemilihan lokasi ini karena menurut data yang diperoleh merupakan daerah dengan jumlah akseptor suntik 3 bulanan yang mengalami kenaikan berat badan banyak.

Pada penelitian ini populasinya adalah Semua akseptor suntik 3 bulanan yang mengalami penambahan berat badan di Klinik Harapan Bunda sebanyak 138 orang. Pada penelitian ini sampelnya adalah Sebagian akseptor suntik 3 Bulanan yang mengalami penambahan berat badan di Klinik Harapan Bunda sebanyak 28 orang. Pada penelitian ini pengambilan sampel secara Simpel random sampling yaitu teknik pengambilan sampel didasarkan jumlah populasi secara acak dan setiap anggota atau unit dari populasi mempunyai kesempatan yang sama untuk diseleksi menjadi sampel (Notoatmodjo, 2010).

Metode pengumpulan data yang menggunakan cara kuesioner atau pertanyaan yang digunakan dalam mendapatkan informasi dari responden untuk laporan tentang pribadinya serta hal-hal yang diketahunya.

\section{HASIL}

\section{Data Umum}

a. Karakteristik Responden Berdasarkan Pendidikan

Karakteristik responden berdasarkan tingkat pendidikan terdiri dari empat kelompok, yakni SD, SMP, SMA, Akademi/Perguruan tinggi yang dijelaskan pada tabel 1.1.

Tabel 1.1 Karakteristik Responden Berdasarkan Pendidikan di Klinik Harapan Bunda Tahun 2017

No Pendidikan Jumlah Persentase

\begin{tabular}{llcr} 
& & & $(\%)$ \\
\hline 1. & SD & 10 & 35,7 \\
2. & SMP & 11 & 39,3 \\
3. & SMA & 5 & 17,9 \\
4. & Akademi/PT & 2 & 7,1 \\
\hline & Total & 28 & 100 \\
\hline
\end{tabular}

Sumber : Data Primer, 2017

Berdasarkan tabel 1.1 terlihat bahwa hampir setengahnya responden berpendidikan SMP sebanyak 11 orang $(39,3 \%)$.

b. Karakteristik Responden Berdasarkan Umur

Karakteristik responden berdasarkan umur responden terdiri dari tiga kelompok, yakni <20 tahun, 20-35 tahun, $>35$ tahun yang dijelaskan pada tabel 1.2.

\section{Tabel 1.2 Karakteristik Responden Berdasarkan Umur di Klinik Harapan Bunda Tahun 2017}

\begin{tabular}{|c|c|c|c|}
\hline$\overline{\mathrm{No}}$ & Umur & Jumlah & $\begin{array}{c}\text { Persentase } \\
(\%)\end{array}$ \\
\hline 1 & $<20$ tahun & 0 & 0,0 \\
\hline 2 & $20-35$ tahun & 4 & 14,3 \\
\hline 3 & $>35$ tahun & 24 & 85,7 \\
\hline & Total & 28 & 100 \\
\hline
\end{tabular}

Berdasarkan tabel 1.2 terlihat bahwa hampir seluruhnya umur responden adalah $>35$ tahun sebanyak 24 responden $(85,7 \%)$.

c. Karakteristik Responden Berdasarkan Pekerjaan

Karakteristik responden berdasarkan status pekerjaan terdiri dari empat kelompok, yakni petani, swasta, PNS, dan Ibu Rumah Tangga yang dijelaskan pada tabel 1.3.

\section{Tabel 1.3 Karakteristik Responden Berdasarkan Pekerjaan di Klinik Harapan Bunda Tahun 2017}




\begin{tabular}{|c|c|c|c|}
\hline \multicolumn{2}{|c|}{$\begin{array}{ll}\text { No } & \text { Pekerjaan }\end{array}$} & \multicolumn{2}{|c|}{$\begin{array}{cc}\text { Jumlah } & \begin{array}{c}\text { Persentas } \\
(\%)\end{array} \\
\end{array}$} \\
\hline 1. & Petani & 1 & 3,6 \\
\hline 2. & Swasta & 6 & 21,4 \\
\hline 3. & $\begin{array}{l}\text { DNS } \\
\text { bu Rumah }\end{array}$ & 1 & 3,6 \\
\hline 4. & Tangga & 20 & 71,4 \\
\hline & Total & 28 & 100 \\
\hline \multicolumn{4}{|c|}{ Sumber : Data Primer, 2017} \\
\hline \multicolumn{4}{|c|}{$\begin{array}{l}\text { Berdasarkan tabel } 1.3 \text { terlihat bahwa } \\
\text { sebagian besar responden merupakan } \\
\text { ibu rumah tangga sebanyak } 20 \\
\text { responden }(71,4 \%) \text {. }\end{array}$} \\
\hline \multicolumn{4}{|c|}{$\begin{array}{l}\text { d. Karakteristik Responden Berdasarkan } \\
\text { Informasi }\end{array}$} \\
\hline \multicolumn{4}{|c|}{$\begin{array}{l}\text { Karakteristik responden berdasarkan } \\
\text { informasi yang pernah diterima } \\
\text { mengenai kontrasepsi suntik } 3 \\
\text { bulanan dapat dikelompokkan } \\
\text { menjadi dua, yakni pernah dan tidak } \\
\text { pernah yang dijelaskan pada tabel 1.4. }\end{array}$} \\
\hline \multicolumn{4}{|c|}{$\begin{array}{l}\text { Tabel 1.4 Karakteristik Responden } \\
\text { Berdasarkan Informasi di Klinik } \\
\text { Harapan Bunda Tahun } 2017\end{array}$} \\
\hline & Informasi & Jumlah & $\begin{array}{l}\text { Persentase } \\
(\%)\end{array}$ \\
\hline & Pernah & 23 & 82,1 \\
\hline & Tidak pernah & 5 & 17,9 \\
\hline & Total & 28 & 100 \\
\hline
\end{tabular}

Sumber : Data Primer, 2017

a. Sikap Akseptor Suntik 3 Bulanan tentang Efek Samping Penambahan Berat Badan Sebelum diberikan Konseling

Tabel 1.6 Distribusi Sikap Akseptor Suntik 3 Bulanan tentang Efek Samping Penambahan Berat Badan di Klinik Harapan Bunda Tahun 2017

Berdasarkan tabel 1.4 terlihat bahwa hampir seluruhnya responden pernah mendapatkan informasi sebanyak 23 responden $(82,1 \%)$.

\begin{tabular}{cccc} 
No & Sikap & Jumlah & Persentase $(\%)$ \\
\hline 1. & Negatif & 16 & 57,1 \\
2. & Positif & 12 & 42,9 \\
\hline & Total & 37 & 100 \\
\hline
\end{tabular}

Sumber : Data Primer, 2017

Dari Tabel 1.6 diketahui bahwa

e. Karakteristik Responden Berdasarkan Sumber Informasi

Karakteristik responden berdasarkan sumber informasi yang pernah didapatkan terdiri dari empat kelompok, yakni tidak pernah, tenaga kesehatan, buku/majalah/koran, radio/TV yang dijelaskan pada tabel 1.5 . sebagian besar dari responden bersikap negatif tentang efek samping penambahan berat badan sebelum diberikan konseling sebanyak 16 responden $(57,1 \%)$.

b. Sikap Akseptor Suntik 3 Bulanan tentang Efek Samping Penambahan Berat Badan Setelah diberikan Konseling 
Tabel 1.7 Distribusi Sikap Akseptor Suntik 3 Bulanan tentang Efek Samping Penambahan Berat Badan di Klinik Harapan Bunda Tahun 2017

\begin{tabular}{llcc}
\hline No & Sikap & Jumlah & $\begin{array}{c}\text { Persentase } \\
(\%)\end{array}$ \\
\hline 1. & Negatif & 8 & 28,6 \\
2. & Positif & 20 & 71,4 \\
\hline & Total & 37 & 100 \\
\hline
\end{tabular}

Sumber : Data Primer, 2017

Dari Tabel 1.7 diketahui bahwa sebagian besar dari responden bersikap positif tentang efek samping penambahan berat badan setelah diberikan konseling sebanyak 20 responden $(71,4 \%)$.

c. Pengaruh Konseling terhadap Sikap Akseptor Suntik 3 Bulanan tentang Efek Samping Penambahan Berat Badan di Klinik Harapan Bunda Tahun 2017

Tabel 1.8 Distribusi Sikap Akseptor Suntik 3 Bulanan tentang Efek Samping Penambahan Berat Badan di Klinik Harapan Bunda Tahun 2017

\begin{tabular}{|c|c|c|c|}
\hline \multirow{2}{*}{$\begin{array}{c}\text { Sikap (Pre } \\
\text { Test) }\end{array}$} & \multicolumn{2}{|c|}{ Sikap (Post Test) } & \multirow[t]{2}{*}{ Jumlah } \\
\hline & Negatif & Positif & \\
\hline Negatif & 8 & 8 & 16 \\
\hline$\%$ & 28,6 & $28,6 \%$ & $57,2 \%$ \\
\hline Positif & 0 & 12 & 12 \\
\hline$\%$ & $0 \%$ & $42,8 \%$ & $42,8 \%$ \\
\hline Jumlah & 8 & 20 & 28 \\
\hline$\%$ & $28,6 \%$ & $71,4 \%$ & $100 \%$ \\
\hline $\begin{array}{c}\text { Uji Paired T } \\
\text { Test }\end{array}$ & $\rho=0,003$ & & \\
\hline
\end{tabular}

Sumber : Data Primer, 2017

Berdasarkan tabel 1.8 menunjukkan bahwa ada pengaruh konseling terhadap sikap akseptor suntik 3 bulanan tentang efek samping penambahan berat badan, yakni dari 28 responden yaitu sebanyak 16 responden $(57,2 \%)$ bersikap negatif dan setelah diberikan konseling kesehatan meningkat menjadi 20 responden $(71,4 \%)$ bersikap positif dan berdasarkan uji statistik dengan menggunakan Paired $t$ Test didapatkan hasil bahwa taraf signifikan sebesar 0,003 adalah kurang dari $0,05(\rho=0,003<\alpha=$ $0,05)$ sehingga dapat dinyatakan bahwa ada pengaruh konseling terhadap sikap akseptor suntik 3 bulanan tentang efek samping penambahan berat badan di Klinik Harapan Bunda Tahun 2017.

\section{PEMBAHASAN}

Sikap Akseptor Suntik 3 Bulanan tentang Efek Samping Penambahan Berat Badan Sebelum diberikan Konseling

Dalam penelitian yang dilakukan pada 28 responden dengan pemberian kuesioner sebanyak 20 soal berupa pernyataan, pada Dari Tabel 1.6 diketahui bahwa sebagian besar dari responden bersikap negatif tentang efek samping penambahan berat badan sebelum diberikan konseling sebagian besar responden yakni 16 responden $(57,1 \%)$ dan 12 responden $(42,9 \%)$ bersikap positif. Hal ini dapat dilihat pada hasil tabulasi dari masing-masing komponen sikap yang meliputi komponen kognitif, afektif dan konatif. Dimana berdasarkan hasil tabulasi sikap negatif yang dimiliki oleh responden terbanyak disebabkan karena rendahnya hasil jawaban responden dalam komponen afektif.

Pada komponen afektif soal nomor 14 yang merupakan pernyataan negatif menyatakan bahwa saya merasa malu dengan perubahan berat badan yang dialami. Pada soal no. 14 tersebut 10 responden menyatakan sangat setuju dan 6 responden menyatakan setuju. Selain itu, pada soal no. 16 yang merupakan pernyataan negatif yakni kenaikan berat badan yang saya alami menimbulkan krisis percaya diri 
dalam bergaul. Dimana dalam menjawab pernyataan tersebut sebanyak 9 responden sangat setuju dan 9 responden setuju. Menurut peneliti anggapan yang seperti inilah yang dapat mendukung akseptor bersikap negatif berkaitan dengan efek samping penambahan berat badan pada kontrasepsi suntik 3 bulanan. Dimana, seharusnya responden menerima keadaannya tanpa harus merasa tidak percaya diri maupun malu. Pendapat diatas didukung oleh teori Wawan 2011 yang menyatakan bahwa komponen afektif (komponen emosional) merupakan komponen yang berhubungan dengan rasa senang terhadap suatu objek. Rasa senang merupakan hal yang positif, sedangkan rasa tidak senang merupakan hal yang negatif ataupun sebaliknya. Komponen ini menunjukkan arah sikap yaitu positif dan negatif (Wawan, 2011). Komponen afektif menyangkut masalah emosional subjektif seseorang terhadap suatu obyek sikap. Secara umum komponen ini disamakan dengan perasaan yang dimiliki seseorang terhadap sesuatu (David, Jonathan, Anne, 1992:140).

Hasil tabulasi pada komponen konatif juga menunjukkan kecenderungan lebih rendah dibandingkan dengan komponen kognitif. Dimana responden menjawab dengan rata-rata nilai rendah pada beberapa pernyataan. Hal tersebut dilihat dari soal no. 18 dengan jenis pernyataan positif ada 8 responden yang menyatakan sangat tidak setuju dan 10 responden yang menyatakan tidak setuju bahwa saya akan berolah raga secara rutin, setelah mengalami perubahan berat badan akibat pemakaian kontrasepsi suntik. Pada soal no. 19 yakni pernyataan negatif terdapat 7 responden sangat setuju dan 9 orang setuju bahwa saya akan melakukan diet ketat akibat kenaikan berat badan setelah menggunakan kontrasepsi suntik. Menurut peneliti anggapan yang seperti inilah yang dapat mendukung akseptor suntik 3 bulanan bersikap negatif berkaitan dengan penanganan efek samping penambahan berat badan. Dimana para responden kurang memahami cara penanganan efek samping yang ditimbulkan kontrasepsi suntik dengan tepat. Pendapat diatas didukung oleh teori Saifuddin 2006 pembatasan makanan dan program olahraga secara rutin atau teratur akan membantu mengontrol kenaikan berat badan, tetapi banyak wanita merasakan hal ini sulit dilaksanakan dalam jangka panjang. Pengaturan diet yaitu dengan cara mengurangi porsi makan nasi diganti dengan banyak mengkonsumsi sayuran (Saifuddin, 2006).

Hasil tabulasi pada komponen kognitif memang tidak menunjukkan kecenderungan terendah, namun pada pernyataan no. 7 dengan jenis pernyataan negatif ada 6 responden sangat setuju dan 12 responden yang menyatakan setuju bahwa menurut saya, diet ketat merupakan upaya yang tepat dalam penanggulangan efek samping kontrasepsi suntik. Hal ini dapat memicu sikap akseptor suntik menjadi negatif. Menurut peneliti diet ketat bukanlah upaya yang tepat bagi penanggulangan efek samping kontrasepsi suntik sebab justru dengan melakukan diet ketat akan menyebabkan gangguan kesehatan. Pendapat tersebut didukung oleh teori yang menyatakan bahwa bahwa orang yang diet terlalu ketat hingga membuat dirinya kekurangan gizi, membuat sel-sel otak "memakan" dirinya sendiri. Pada saat yang sama, rasa lapar hanya akan menambah buruk kondisi sel otak. 
Hal ini disebabkan oleh fakta bahwa sel-sel otak tidak menerima nutrisi yang cukup. Menurut studi yang dilakukan di Albert Einstein College of Medicine di New York City, sel-sel otak mulai makan dirinya sendiri untuk mengambil keuntungan dari sumber energi terakhir yang tersedia. Proses ini disebut autophagy, dan itu mengarah pada rendahnya komponen internal sel (Genius Beauty, 2011).

Berdasarkan penjelasan yang ada di atas sejalan dengan konsep teori dari beberapa faktor yang mempengaruhi sikap akseptor suntik 3 bulanan tentang efek samping penambahan berat badan yang dipengaruhi oleh pengeahuan, informasi, kondisi keluarga, pendidikan, lingkungan yang berdampak terhadap penilaian dan tindakan penanganan kontrasepsi suntik 3 bulan.

Dari beberapa faktor yang telah dijelaskan tersebut pendidikan juga memiliki pengaruh yang besar terhadap pengembangan sikap seseorang Berdasarkan tabel 1.1 terlihat bahwa hampir setengahnya responden berpendidikan SMP sebanyak 11 orang (39,3\%). Sedangkan dari hasil tabulasi silang antara umur dengan sikap akseptor suntik 3 bulanan menunjukkan bahwa pada kelompok pendidikan SD sejumlah 9 responden $(32,1 \%)$ memiliki sikap negatif. Menurut peneliti disebabkan karena pendidikan SD merupakan tingkat pendidikan dasar. Pada tingkat pendidikan dasar ini akan mempengaruhi pola berpikir responden. Dimana pola pikir ini akan berdampak pada kemampuan seseorang dan berpengaruh terhadap sikap responden terhadap efek samping kontrasepsi suntik 3 bulanan. Hal ini sesuai dengan teori yang dikemukakan Notoadmodjo yakni pendidikan berarti bimbingan yang diberikan seseorang terhadap perkembangan orang lain menuju ke arah cita-cita tertentu. Pada umumnya makin tinggi pendidikan seseorang makin mudah menerima informasi, sehingga semakin banyak pula pengetahuan yang dimiliki. Sebaliknya pendidikan yang kurang akan menghambat perkembangan sikap seseorang terhadap nilai-nilai yang baru dikenal (Notoadmojo, 2010).

Berdasarkan tabel 1.3 terlihat bahwa sebagian besar responden merupakan ibu rumah tangga sebanyak 20 responden (71,4\%). Pada hasil tabulasi silang antara pekerjaan dengan sikap akseptor suntik 3 bulanan didapatkan ibu rumah tangga sebanyak 12 (42,9\%) bersikap negatif. Menurut peneliti ibu yang tidak bekerja, yakni ibu rumah tangga sebanyak 20 responden $(71,4 \%)$ memiliki sikap negatif, karena ratarata ibu mengerjakan pekerjaan rumah tangga sendiri karena tidak mempunyai pembantu, sehingga waktu luang yang dimiliki oleh ibu digunakan untuk beristirahat atau menonton televisi dengan tayangan sinetron dibandingkan dengan menambah wawasan kesehatan melalui kunjungan ke tenaga kesehatan maupun meluangkan waktunya untuk sharing dengan tetangga yang memiliki pengalaman yang sama. Hal ini sesuai dengan teori yang dikemukakan oleh Rahmat (2009) yang menyatakan bahwa hal hal yang menyangkut dengan pendapatan, pendidikan dan pekerjaan dalam lingkungan keluarga akan memberikan pengaruh bagi individu terutama terhadap perkembangan pada dirinya termasuk status sosial ekonomi dalam keluarga tersebut. 


\section{Sikap Akseptor Suntik 3 Bulanan tentang Efek Samping Penambahan Berat Badan Setelah diberikan Konseling}

Data hasil tabulasi pada tabel 1.7 menunjukkan bahwa sebagian besar dari responden bersikap positif tentang efek samping penambahan berat badan setelah diberikan konseling sebanyak 20 responden $(71,4 \%)$. Sedangkan hasil penelitian pada tabel 1.8 menunjukkan bahwa sebelum diberikan konseling responden yang bersikap negatif sebanyak 16 responden $(57,2 \%)$ dan setelah mendapatkan konseling responden yang memiliki sikap negatif sebanyak 8 responden $(28,6 \%)$. Diantara 16 responden yang memiliki sikap negatif, 8 responden berubah sikapnya menjadi positif. Responden yang mengalami perubahan sikap negatif menjadi positif sebanyak 8 responden $(50 \%)$ dari 16 responden $(57,2 \%)$ yang memiliki sikap negatif sebelum diberi konseling.

Dari masing-masing komponen sikap yaitu komponen kognitif, afektif dan konatif yang menyebabkan sikap akseptor suntik 3 bulanan menjadi positif yaitu pada komponen konatif yang memiliki peningkatan tertinggi dibandingkan kognitif dan afektif. Hal ini diketahui dengan adanya pengaruh yang signifikan terutama pada pernyataan no.18 dengan jenis pernyataan positif. Sebelum diberikan konseling sebanyak 8 responden yang menyatakan sangat tidak setuju dan 10 responden yang menyatakan tidak setuju. Namun setelah diberikan konseling sebanyak 20 responden menyatakan sangat setuju dan 8 responden menyatakan setuju bahwa akan berolah raga secara rutin, setelah mengalami perubahan berat badan akibat pemakaian kontrasepsi suntik. Hal ini menunjukkan bahwa responden telah menyadari dan mengerti tentang cara penanggulangan kontrasepsi suntik 3 bulanan, sehingga jika seseorang telah menyadari cara penanggulangan yang tepat maka mereka akan melakukan usaha yang terbaik dalam melakukan penanggulangan kontrasepsi suntik 3 bulanan untuk mengontrol penambahan berat badan yang dialami. Hal ini sesuai dengan teori yang dikemukakan oleh Wawan (2011) yang menyatakan bahwa sikap adalah kondisi mental yang kompleks yang melibatkan keyakinan dan perasaan, serta diposisikan untuk bertindak dengan cara tertentu.

Berdasarkan hasil tabulasi juga didapatkan hasil peningkatan pada komponen afektif, meskipun peningkatan pada komponen afektif lebih rendah dari konatif. Hasil yang didapatkan dari tabulasi masing masing komponen sikap, pada aspek afektif pada soal no. 11 dengan pernyataan positif yang berkaitan dengan rasa kepercayaan diri setelah mengalami kenaikan berat badan, sebelum dilakukan konseling sebanyak 7 responden menyatakan sangat tidak setuju dan setelah diberikan konseling berubah menjadi sebanyak 12 responden menyatakan sangat setuju dengan pernyataan tersebut. Menurut peneliti pemberian informasi yang berkaitan dengan kontrasepsi suntik 3 bulanan melalui konseling mampu meberikan dampak positif terhadap sikap akseptor. Pada umumnya, individu cenderung untuk memiliki sikap yang konformis atau searah dengan sikap orang yang dianggap penting (Saifuddin, 2000). 
Pada komponen kognitif juga tidak kalah penting dalam pembentukan sikap. Meskipun, peningkatan yang terjadi lebih rendah dibandingkan komponen afektif dan konatif, akan tetapi komponen kognitif ini memiliki nilai rata-rata tertinggi pada hasil tabulasi post test. Dimana pada komponen kognitif peningkatan yang signifikan terdapat pada soal nomor 7 dengan jenis pernyataan negatif yang berkaitan dengan penanggulangan efek samping penambahan berat badan. Responden dengan jumlah sebanyak 22 responden menyatakan sangat tidak setuju dan 6 responden menyatakan tidak setuju apabila mereka melakukan diet ketat sebagai upaya penanggulangan efek samping dari kontrasepsi suntik yang tepat. Menurut peneliti hal ini menunjukkan bahwa responden telah mampu mengtahui dan memahami upaya penangulangan efek samping dari kontrasepsi suntik 3 bulanan yang tepat dengan mempertimbangkan mana yang baik dan mana yang kurang baik untuk kesehaannya. Dimana responden telah mengetahui bahwa diet ketat bukanlan upaya yang tepat dan justru dapat mengganggu kesehatannya. Pemikiran yang demikian akan membawa dampak pada perubahan sikap yang lebih positif bagi para akseptor suntik 3 bulanan. Hal ini didukung oleh teori Maulana (2007) yang berkaitan dengan fungsi instrumental dari sikap. Maulana menyatakan bahwa bila objek sikap dapat membantu seseorang dalam mencapai tujuannya, maka orang akan bersikap positif terhadap objek tersebut, demikian sebaliknya bila objek sikap menghambat dalam pencapaian tujuan, maka orang akan bersikap negatif terhadap objek sikap yang bersangkutan (Wawan, 2011).
Sikap akseptor suntik 3 bulanan tentang efek samping penambahan berat badan dipengaruhi oleh umur, berdasarkan tabel 1.2 terlihat bahwa sebagian besar umur responden adalah > 35 tahun sebanyak 24 responden $(85,7 \%)$. Pada hasil tabulasi silang antara umur dengan sikap menunjukkan bahwa umur $>35$ tahun sebanyak 18 (64,3\%) bersikap positif. Menurut peneliti ibu atau responden dengan usia > 35 tahun merupakan usia yang sudah matang dan dewasa, sehingga dalam melakukan tindakan penanganan efek samping kontrasepsi suntik 3 bulanan responden mampu mengambil keputusan yang tepat dengan mempertimbangkan baik dan buruk suatu tindakan yang dilakukan. Dan menurut Hurlock (1998) dalam Wawan (2011) bahwa semakin cukup umur, tingkat kematangan dan kekuatan seseorang akan lebih matang dalam berpikir dan bekerja.

Hasil tabulasi yang telah dijelaskan pada tabel 1.4 terlihat bahwa sebagian besar responden pernah mendapatkan informasi sebanyak 23 responden $(82,1 \%)$. Pada hasil tabulasi silang antara informasi dengan sikap akseptor suntik 3 bulanan didapatkan sebanyak $16(57,1)$ responden yang pernah mendapat informasi bersikap positif. Menurut peneliti, dari 16 $(57,1 \%)$ responden yang pernah mendapat informasi, sehingga semakin banyak ibu memperoleh informasi tentang efek samping kontrasepsi suntik maka ibu akan sadar akan pentingnya informasi serta memberikan pengaruh besar terhadap sikap ibu. Apabila ibu diberikan informasi tentang efek samping kontrasepsi suntik dengan jelas, benar dan komprehensif maka ibu akan mempunyai sikap yang positif tentang efek samping kontrasepsi suntik 
Pendapat ini didukung oleh teori Nesi \& Yunetra 2013 yang menyatakan bahwa pendidikan yang bertujuan untuk memberikan informasi dan memastikan pengetahuan dan pemahaman masyarakat tentang masalah kesehatan, serta menetapkan keputusan untuk mengubah perilaku atas dasar informasi kesehatan yang telah diberikan akan berdampak positif bagi masyarakat.

Sumber informasi juga berpengaruh terhadap perubahan sikap. Berdasarkan tabel 1.5 terlihat bahwa sebagian besar responden pernah mendapatkan sumber informasi melalui tenaga kesehatan sebanyak 15 responden (53,6\%). Pada hasil tabulasi silang antara sumber informasi dengan sikap akseptor suntik 3 bulanan didapatkan bahwa sebanyak $11 \quad(39,3 \%)$ responden mendapat informasi dari petugas kesehatan bersikap positif. Menurut peneliti, informasi yang didapat responden sebanyak $11 \quad(39,3 \%)$ melalui tenaga kesehatan tentang efek samping kontrasepsi suntik 3 bulanan menyebabkan responden tahu, mengerti dan memahami bagaimana cara menyikapi perubahan berat badan yang sedang dialami dan informasi tersebut lebih jelas dan benar, karena tenaga kesehatan lebih mengerti serta memiliki dasar pendidikan yang bisa dipercaya dalam pemberian informasi. Media mempunyai peranan penting dalam penyampaian informasi, adanya informasi baru mengenai suatu hal yang memberikan landasan kognitif baru bagi terbentuknya sikap seseorang terhadap sesuatu hal (Notoatmodjo, 2011).

\section{Pengaruh Konseling terhadap Sikap Akseptor Suntik 3 Bulanan tentang Efek Samping Penambahan Berat Badan}

Hasil tabulasi pada tabel 5.6 diketahui bahwa sebagian besar dari responden bersikap negatif tentang efek samping penambahan berat badan sebelum diberikan konseling sebanyak 16 responden $(57,1 \%)$ dan pada tabel 5.7 menunjukkan bahwa sebagian besar dari responden bersikap positif tentang efek samping penambahan berat badan setelah diberikan konseling sebanyak 20 responden $(71,4 \%)$. Hasil penelitian menunjukkan bahwa terdapat perbedaan bermakna skor sikap akseptor suntik 3 bulanan tentang efek samping penambahan berat badan sebelum dan setelah dilakukan intervensi konseling.

Sikap akseptor suntik 3 bulanan tentang efek samping penambahan berat badan di Klinik Harapan Bunda sebelum dan setelah diberikan intervensi konseling berdasarkan hasil uji statistik dengan menggunakan Paired $T$ Test didapatkan nilai $\mathrm{p}=$ 0,003 ( $\mathrm{p}<0,05$ ) maka H1 diterima, yang artinya ada pengaruh konseling terhadap sikap akseptor suntik 3 bulanan tentang efek samping penambahan berat badan di Klinik Harapan Bunda Pangkalan Bun.

Konseling yang diberikan secara benar dan komprehensif pada seseorang akan berpengaruh pada sikap yang positif. Dapat dilihat pada teori bahwa proses konseling pada dasarnya proses perubahan perilaku individu dalam sistem, dan kepedulian utamanya terletak pada interaksi individu dalam sistem. Individu dalam sistem mempunyai tujuan yang ingin dicapai melalui konseling. Tujuan yang ingin dicapai adalah perubahan perilaku pada diri individu, baik dalam bentuk pandangan, sikap, sifat maupun keterampilan yang lebih memungkinkan individu dapat menerima, mewujudkan diri, mengembangkan diri, mencegah dan 
mampu mengatasi permasalahan secara optimal sebagai wujud dari individu yang memiliki pribadi mandiri (Corones, 2009).

Hal ini sejalan dengan penelitian yang dilakukan oleh Loriana (2009) tentang efek konseling terhadap pengetahuan, sikap, dan kepatuhan berobat penderita tuberkulosis paru di wilayah kerja dinas kesehatan kota Samarinda bahwa terdapat perbedaan yang bermakna pengetahuan tentang kepatuhan berobat penderita TB paru sebelum dan sesudah mendapatkan konseling, terdapat perbedaan yang bermakna sikap tentang kepatuhan berobat penderita TB Paru sebelum dan sesudah mendapatkan konseling serta terdapat perbedaan yang bermakna tingkat kepatuhan berobat pada penderita TB paru sebelum dan sesudah mendapatkan konseling. Dapat disimpulkan bahwa adanya efek dari konseling terhadap pengetahuan, sikap dan kepatuhan berobat penderita TB Paru di wilayah kerja Dinas Kesehatan kota Samarinda.

Penelitian Hestuningtyas (2013) tentang pengaruh konseling gizi terhadap pengetahuan, sikap, praktik ibu dalam pemberian makan anak, dan asupan zat gizi anak stunting usia 1-2 tahun di Kecamatan Semarang Timur bahwa konseling gizi dapat meningkatkan pengetahuan, sikap, praktik ibu dalam pemberian makan anak, dan asupan zat gizi anak secara signifikan.

Penelitian Rogers (1974) mengungkapkan bahwa sebelum orang mengadopsi perilaku baru (berperilaku baru), didalam diri orang tersebut terjadi proses yang berurutan, yakni : awareness (kesadaran), Interest (tertarik kepada stimulus), evaluation (menimbang-nimbang baik dan tidaknya stimulus bagi dirinya), trial (orang telah mulai mencoba perilaku baru), adoption (subjek telah berperilaku baru sesuai dengan pengetahuan, kesadaran, dan sikapnya terhadap stimulus). Apabila penerimaan perilaku baru atau adopsi perilaku melalui proses seperti ini didasari oleh pengetahuan, kesadaran, dan sikap yang positif maka perilaku tersebut akan menjadi kebiasaan atau bersifat langgeng (Notoatmodjo, 2003).

\section{KESIMPULAN DAN SARAN}

\section{Simpulan}

Berdasarkan hasil penelitian maka peneliti menarik kesimpulan bahwa :

1. Sikap akseptor suntik 3 bulanan tentang efek samping penambahan berat badan sebelum diberikan konseling sebagian besar adalah bersikap negatif.

2. Sikap akseptor suntik 3 bulanan tentang efek samping penambahan berat badan setelah diberikan konseling sebagian besar adalah bersikap positif.

3. Ada pengaruh konseling terhadap sikap akseptor suntik 3 bulanan tentang efek samping penambahan berat badan di Klinik Harapan Bunda Pangkalan Bun.

\section{Saran}

\section{Bagi Bidan}

Diharapkan bidan dapat meningkatkan pemberian konseling dan motivasi yang telah diberikan dengan menggunakan alat peraga yang lebih baik serta 
lebih menarik seperti pembuatan lembar balik, buklet, leaflet yang lebih menarik untuk meningkatkan sikap pada aspek afektif dan konatif, yakni rasa percaya diri kepada akseptor tentang efek samping kontrasepsi suntik serta meningkatkan dan memberikan solusi cara menyikapi efek samping yang terjadi.

\section{Bagi Institusi Pendidikan}

Diharapkan hasil penelitian ini digunakan sebagai wacana guna pembentukan tim pengabdian masyarkat melalui kelompok kecil untuk dapat terjun kemasyarakat dalam memberikan konseling dengan menggunakan alat peraga yang lebih baik serta lebih menarik, seperti pembuatan lembar balik, buklet, leaflet guna meningkatkan pemahaman akseptor khususnya kontrasepsi suntik.

\section{Bagi Peneliti Selanjutnya}

Diharapkan peneliti selanjutnya dapat mengembangkan penelitian dengan melakukan penelitian tentang faktor lain yang mempengaruhi negatifnya sikap akseptor suntik 3 bulanan tentang efek samping penambahan berat badan yaitu berdasarkan karakteristik pengetahuan, umur, kondisi keluarga, lingkungan, dan pendidikan. Dan melakukan penelitian lebih mendalam dengan jumlah populasi dan sampel lebih banyak serta dengan metode penelitian kualitatif. Peneliti selanjutnya juga diharapkan dapat meneliti efektivitas perbedaan konseling di tempat pelayanan kesehatan dan di rumah dengan sikap akseptor suntik 3 bulanan tentang efek samping dari kontrasepsi.

\section{DAFTAR PUSTAKA}

Arikunto, S. 2010. Prosedur Penelitian Suatu pendekatan Praktik. Jakarta: PT Rineka

Arikunto, Prof. Dr. Suharsimi. 2006. Prosedur Penelitian Suatu Pendekatan Praktik. Jakarta:

PT. Rineka Cipta.

Azwar Saifuddin, 2011. Sikap Manusia Teori dan

Pengukurannya, Yogyakarta: Pustaka Belajar.

Arum Setya, D.N, Sujiyatini. 2010. Panduan Lengkap Pelayanan KB Terkini. Yogyakarta:

Mitra Cendekia.

Desmita. 2008. Psikokolgi Perkembangan. Bandung Rosda Karya.

Effendi, 2004. Dasar-Dasar Keperawatan Kesehatan Masyarakat. Jakarta: EGC.

Hanafi. 2004. Buku Acuan Pelayanan Kontrasepsi. Jakarta : ISBN

Handayani, Sri. 2010. Buku Ajar Pelayanan Keluarga

Berencana. Yogyakarta:

Pustaka Rihama

Hawa, Siti. Perbedaan Antara Pemakaian Kontrasepsi Suntik Kombinasi dan Suntik Depomedroxy Progesteron Acetat (DMPA) dalam Perubahan Berat Badan. http://alumni.unair.ac.id/detail.p hp?id=59103\&faktas=Kedokter an (Sitasi 5 Maret 2014).

Hestuningtyas. 2013. Pengaruh Konseling Gizi terhadap Pengetahuan, Sikap, Praktik Ibu dalam Pemberian Makan 
Anak, dan Asupan Zat Gizi Anak Stunting Usia 1-2 Tahun di Kecamatan Semarang Timur. Diakses pada tanggal 20/6/2014 11:31PM.

Hidayat, A. 2012. Riset Keperawatan dan Teknik Penulisan Ilmiah. Jakarta: Salemba Medika.

Hidayat, A. 2012, Metode Penelitian Kebidanan dan Teknik Analisa Data. Jakarta: Salemba Medika. Irianto, Koes. 2012. Keluarga Berencana Untuk Paramedis Dan Non Medis. Jakarta Yramawidya.

Loriana, Rina. 2009. Efek Konseling terhadap Pengetahuan, Sikap, dan Kepatuhan Berobat Penderita Tuberkulosis Paru di Wilayah Kerja Dinas Kesehatan Kota Samarinda. Diakses pada tanggal 22/6/2014 10:31PM.

Mardyaningsih, Wulansari, Purwanti. 2012. Analisis Perbedaan Berat Badan Sebelum dan Selama Menggunakan KB Suntik 3 Bulan di BPS Ny. Ismiati Desa Jatirunggo Kecamatan Pringapus Kabupaten Semarang.RHK, 6.

Maritaliadewi. 2012. Asuhan Kebidanan Nifas dan Menyusui. Yogyakarta: Pustaka Pelajar

Maulana. 2009. Promosi Kesehatan. Jakarta: EGC.

Nesi \& Yunitra. 2013. Promosi Kesehatan Dalam Pelayanan Kebidanan. Jakarta : Salemba Medika.

Notoatmodjo, $\quad$ Soekidjo. 2010. Metodologi Penelitian Kesehatan. Jakarta: PT Rineka Cipta.
Notoatmodjo, Soekidjo. 2012. Promosi Kesehatan Teori dan Aplikasi. Jakarta: PT Rineka Cipta.

Nursalam, 2011. Konsep dan Penerapan Metodologi Penelitian Ilmu Keperawatan Pedoman Skripsi, Tesis dan Instumen Penelitian Keperawatan. Jakarta: Salemba Medika.

Nursalam, 2008. Pendidikan Dalam Keperawatan. Jakarta: Salemba Medika.

Rahmat, H. 2009. Ilmu Perilaku Manusia.Jakarta : CV. Trans Info Media.

Riwidikdo, Handoko. 2009. Statistik Kesehatan. Jogjakarta: Mitra Cendikia.

Sarwono prawihardjo, 2011. Psikologi Remaja. Jakarta: Rajawali Pers.

Saryono. 2011. Metodologi Penelitian Kesehatan. Jogjakarta: Mitra Cendekia Press

Sunarto \& Hartono.(2006). Perkembangan Peserta Didik. Jakarta: PT.Asdi Mahasatya.

Sulistyaningsih, 2011. Metodologi Penelitian Kebidanan KuantitatifKualitatif, Yogyakarta:

Graha Ilmu.

Wawan, 2010. Teori dan Pengukuran $\begin{array}{ll}\text { Pengetahuan, } & \text { Sikap } \\ \text { dan Perilaku } & \text { Manusia. }\end{array}$

Yogyakarta: Nuha Medika.

Yanti. 2011. Buku Ajar Kesehatan Reproduksi untuk Mahasiswa Kebidanan. Yogyakarta: 